\title{
Biotransportation of Heavy Metals in Eichhornia crassipes (MART.) Solms. Using X-Ray Fluorescence Spectroscopy
}

\author{
HIREN B. SONI and SHEJU THOMAS \\ P.G. Department of Environmental Science \& Technology (EST), \\ Institute of Science \& Technology for Advanced Studies \&Research (ISTAR) \\ Vallabh Vidyanagar - 388120 (Gujarat) India. \\ http://dx.doi.org/10.12944/CWE.10.1.02
}

(Received: March 13, 2015; Accepted: March 30, 2015)

\begin{abstract}
Biomonitoring study of heavy metals was done at pilgrimage freshwater ecosystems of Central Gujarat, India, to ascertain the degree of 17 metals. The study focused on the assessment of available metals in Eichhornia crassipes (Mart.) Solms., collected from sacred palustrine habitat (Dakor Sacred Wetland - DSW) of Gujarat, to be used as a biomonitor (active) species, in comparison with sediment (abiotic monitor) for metal pollution. The results were obtained by analyzing elemental composition of rhizome, tuber, stem and leaves of native aquatic freshwater macrophyte (Eichhornia crassipes) along with bottom sediments for 17 heavy metals (Ti, $\mathrm{Cr}, \mathrm{Mn}, \mathrm{Fe}, \mathrm{Ni}, \mathrm{Cu}, \mathrm{Zn}, \mathrm{Br}, \mathrm{Rb}, \mathrm{Sr}$, $\mathrm{Y}, \mathrm{Zr}, \mathrm{Nb}, \mathrm{Ba}, \mathrm{Pb}, \mathrm{Sm}, \mathrm{Ir}$ ) using Wavelength Dispersive X-Ray Fluorescence (WD-XRF) (Omania Software). The highest concentrations were observed in rhizome (12) in assay species of aquatic macrophyte, followed by tuber and stem (10 each), and least content was observed in leaf (8). Toxic heavy metals ( $\mathrm{Ti}, \mathrm{Mn}, \mathrm{Fe}, \mathrm{Zn}, \mathrm{Br}, \mathrm{Sr}, \mathrm{Zr}, \mathrm{Pb}$ ) were detected, prone to cardiac, respiratory, musculoskeletal and hepatic interferences in indigenous human clusters in and around studied wetland. Eichhornia crassipes was proved to be the best phytoaccumaltor species for heavy metals, exhibited by highest translocation factor for $\mathrm{Zn}, \mathrm{Sr}, \mathrm{Zr}$, and $\mathrm{Pb}$, and bioaccumulation factor for $\mathrm{Mn}, \mathrm{Rb}, \mathrm{Sr}$ and Fe metals. Present research indicates that $E$. crassipes (Mart.) Solms. is better remediator species for mobility of $\mathrm{Pb}, \mathrm{Zr}$ and $\mathrm{Sr}$ metals. Thus, Eichhornia crassipes can be used for an effective abatement of contaminated aquatic sites.
\end{abstract}

Key words: Eichhornia crassipes; Elemental composition; Translocation factor; Bioaccumulation factor; Mobility index.

\section{INTRODUCTION}

Aquatic macrophyte are aquatic plants growing in or near shores; extremely important components of biotic communities; essential for oxygen production, nutrient cycling, water quality control, and sediment stabilization. They provide favourable habitats and shelters for aquatic life; considered as efficient accumulators of heavy metals and minerals (Vardanyan and Ingole, 2006). Due to these characteristics, such plants can be used successfully as biological monitors and accumulators of aquatic environments contaminated with metals. Metal pollution is very stern problem due to their non-biodegradable and hazardous nature, having momentous bioaccumulation capacity in living tissues of plants and animals (Tsekova, 2010). Point and non-point deposits of contaminants magnify the concentrations of meager elements in aquatic bodies, resulting in their sporadic accretion in sediments (Dunbabin and Bowmer, 1992). Aquatic macrophytes accumulate elements in roots and shoots (Pip and Stepaniuk, 1992; Jackson, 1998). Aquatic plants exhibit diverse behavior in context of their ability to mount up the elements in roots, stems, and leaves. In aquatic ecosystems, pollutant loads are erratic and are rapidly diluted, plant tissue analysis provides time-integrated information about 
the quality of the ecosystem (Baldantoni et al., 2005). Now-a-days, various types of methods are used to lessen the unwarranted heavy metals from aqueous environ, which are sometimes unproductive or costly when heavy metals exist in momentous concentration (Ahluwalia and Goyal, 2007). Phytoremediation (biomonitoring) is an effectual, inexpensive, and preferred clean-up method to be used at moderately contaminated habitats; using selective aquatic plant species for gradient accumulation of heavy metals (Szymanowska et al., 1999; Demirezen and Aksoy, 2004; Deng et al., 2004; Vardanyan and Ingole, 2006). The increase of environmental problems and paucity of heavy metal pollution studies make the important asset to find autochthonous species capable of cleaning up aquatic environments contaminated by metals.

In past, researchers carried out biomonitoring study of heavy metals uptake by aquatic macrophytes at selected freshwater ecosystems of Gujarat (Nirmal et al., 2006; 2007; 2008; 2012). Moreover, previous studies focusing on profile of abiotic and biotic components of Dakor Sacred Wetland (DSW) was investigated by Soni and Thomas (2013 abcde; Thomas and Soni, 2013). However, the present study site (DSW) has not been focused to study elemental profile and biomonitoring of heavy metals and minerals in aquatic macrophyte (E. crassipes) yet. Hence, an attempt was made to assess the potential of $E$. crassipes to accumulate available heavy metals (17) in different plant-parts, using Wavelength Dispersive X-Ray Fluorescence Spectroscopy (WD-XRF, AxiosMAX, PANalytical, Netherland).

\section{MATERIALS AND METHODS}

\section{Study Area}

Dakor Sacred Wetland (DSW), District Anand, Central Gujarat, India $\left(22.75^{\circ} \mathrm{N}, 73.15^{\circ} \mathrm{E}\right)$, falls in 4-B Gujarat-Rajwara, the semi-arid lands of Gujarat (Rodgers and Panwar, 1988). Average elevation of area is 49 meters ( 160 feet) above $\mathrm{msl}$; temperature ranges from lowest $12{ }^{\circ} \mathrm{C}$ (Winter) to highest $34^{\circ} \mathrm{C}$ (Summer). According to 2001 census, the human population of Dakor is around 23,784 with an average literacy rate of $76 \%$. More than $70-80$ lakh devotees visit the shrine every year (Figure 1, Table 1).

\section{Water and Sediment Sampling}

Surface water and composite sediment samples were taken from transactional regime of the study area in the month of October, 2014. Surface water samples were samples in pre-cleaned polyethylene bottles (two litres), filtered using $0.45 \mu$ filters, preserved by addition of few drops of Conc. $\mathrm{HNO}_{3}$, and stored in icebox at $-4{ }^{\circ} \mathrm{C}$, brought to the laboratory for analysis. Composite sediment samples were taken from the pond using grab sampler,

Table 1: Site fidelity of Dakor Sacred Wetland (DSW), Gujarat, India

\section{Site fidelity of Dakor Sacred Wetland (DSW),} Gujarat, India
Coordinates

Biotic Province

Area (ha)

Wind Direction

Shape

Maximum Depth (ft)

Average Depth $(\mathrm{m})$

Mean Temperature $\left({ }^{\circ} \mathrm{C}\right) \quad 27$

Average Rainfall $(\mathrm{cm}) \quad 95$

Wind Velocity $\left(\mathrm{kmh}^{-1}\right) \quad 5$

Average Humidity (\%) 43

Phytoplankton $75^{*}$

Zooplankton $52^{*}$

Aquatic Macrophyte $18^{*}$

Waterfowls $88^{\#}$

Fish 12\#

Herpetofauna $14^{\#}$

Mammals $10^{\#}$

Significance Renowned Hindu

Recreational Activities Fishing, Boating,

Anthropogenic

Threats
Cutting, Uprooting, Lopping, Thatching, Roofing, and Trading of Aquatic Plants Hunting and Poaching of Indian Flap Shell Turtle Lyssemis punctata)

\footnotetext{
* Soni and Thomas (2013 ac); \# Singh et al. (2002)
} 
preserved on-site in air-dried polyethylene bags, labeled carefully, and brought to the laboratory (Trivedy and Goel, 1986; Maiti, 2003; APHA, 2012).

\section{Plant Sampling}

For the present study, the native aquatic macrophyte Eichhornia crassipes (Mart.) Solms. was selected as an active biomonitor species for the elemental composition ( $\mathrm{Ti}, \mathrm{Cr}, \mathrm{Mn}, \mathrm{Fe}, \mathrm{Ni}, \mathrm{Cu}$, $\mathrm{Zn}, \mathrm{Br}, \mathrm{Rb}, \mathrm{Sr}, \mathrm{Y}, \mathrm{Zr}$, Nb, Ba, Pb, Sm, Ir) in different plant-parts (rhizome, tuber, stem, leaves). Healthy aquatic plant individuals were collected from 0.5 $1.0 \mathrm{~m}$ depth, washed with pond water to remove unwanted elements. The plant-parts were kept in zipped air-tight moisture-ridden polyethylene bags, and analyzed in laboratory for elemental composition (Figures 2ab). To avoid metal contamination in collected samples, polythene objects were used (Allen, 1989). Plant species was identified on-site, and were further authenticated referring standard published literature (Shah, 1962; Biswas and Calder, 1994).

\section{Laboratory Work}

Chemical Analysis of Water, Sediment, and Plant

Sediment samples were air-dried, sieved using $2 \mathrm{~mm}$ sieve, and analyzed in WD-XRF, AxiosMAX, PANalytical, Netherland. The selected plant species was cleaned using double ionized water, and sorted into different plant-parts: rhizomes, tuber, stem, and leaves. The $50 \mathrm{~g}$ of each fresh sample was dried at $80{ }^{\circ} \mathrm{C}$ in hot air oven for 48 hrs. The samples of sediment and plant-parts were analyzed for detection of heavy metal concentrations (as listed earlier). For this, five grams of dry powder of both samples was weighed. Before analysis, samples were treated by preparing a mixture of powdered samples and Boric Acid $\left(\mathrm{H}_{3} \mathrm{BO}_{3}\right)$. Later, treated samples were converted into powder pellets using high pressure of 20 tones for 20 seconds with the help of hydraulic pressure. The elements were analyzed using Wavelength Dispersive X-Ray Fluorescence Spectroscopy (WD-XRF, AxiosMAX, PANalytical, Netherland), embodied with scintillation and flow counter detectors, and ultra-thin X-ray tube

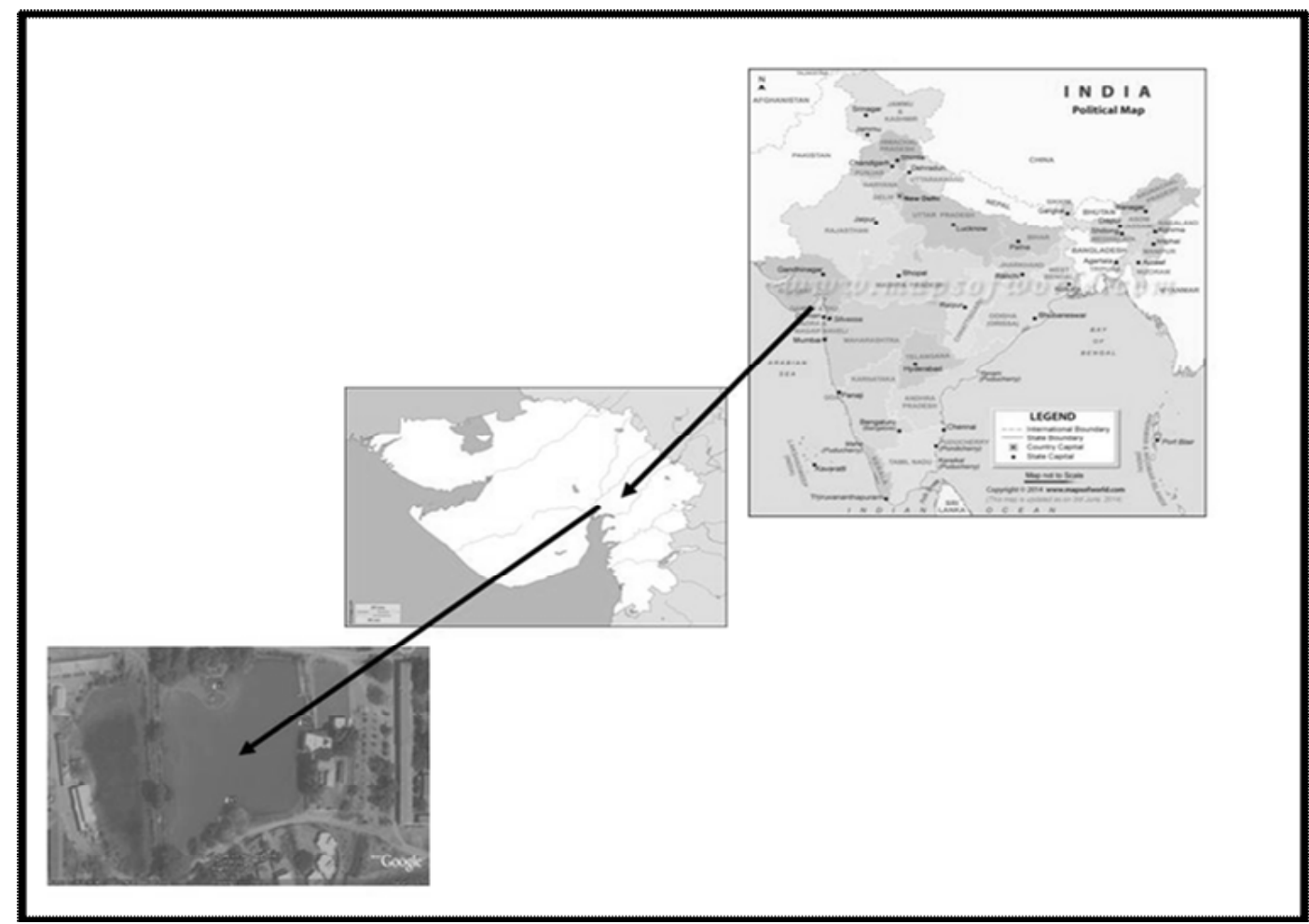

Fig. 1: Holistic View of Dakor Sacred Wetland (DSW), Central Gujarat, India 
using Standard Less Omnian Software (Epsilon $3^{\mathrm{x}}$ ) at Sophisticated Instrumentation Centre for Applied Research and Testing (SICART), Vallabh Vidyanagar, Gujarat, India. The heavy metals concentration was determined and expressed in percentage (\%).

\section{Data Analysis}

Elemental composition was ere evaluated for both sediment and plant-parts. Pearson correlation coefficient ( $r$ ) was derived for plant parts-pairs to speculate the differences between elemental combinations in rhizome, tuber, stem and leaf system. The obtained values were analyzed statistically using Paleontological Statistical Software (PAST, Version 3.04, USA). Furthermore, Translocation factor (TF) [ratio of shoot to root metal concentration] was used as an indicator of the internal metal transport system from root to shoot systems (Deng et al., 2004). TF $>1$ indicates the efficiency of plant to translocate the metals from root to shoot (Stoltz and Greger, 2002). Bioaccumulation factor (BAF) [level in root / labile metal level in Near Root Sediment (NRS)]

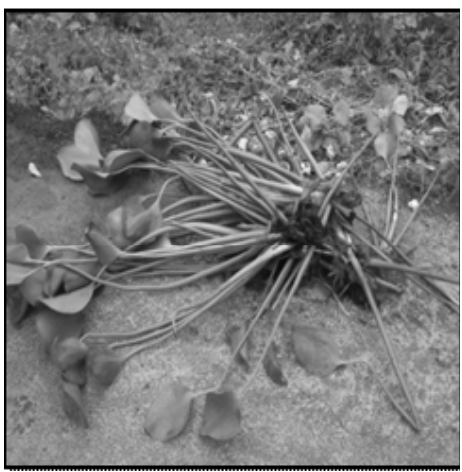

Fig. 2a: On-field sampling

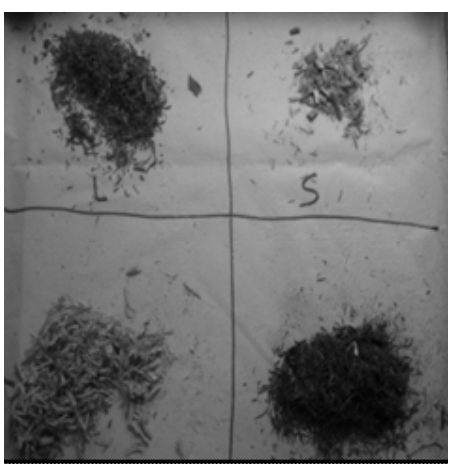

Fig. 2b: Sample preparation

Table 2a: Heavy metals composition in plant-parts of Eichhornia crassipes

\begin{tabular}{lcccc}
\hline Heavy Metals & Leaf & Stem & Tuber & Rhizome \\
\hline Titanium $(\mathrm{Ti})$ & 0.050 & 0.032 & 0.233 & 0.192 \\
Chromium $(\mathrm{Cr})$ & - & - & 0.006 & 0.005 \\
Manganese $(\mathrm{Mn})$ & 0.028 & 0.026 & 0.012 & 0.186 \\
Iron $(\mathrm{Fe})$ & 0.166 & 0.174 & 0.108 & 2.627 \\
Nickel $(\mathrm{Ni})$ & - & - & 0.004 & - \\
Copper $(\mathrm{Cu})$ & - & 0.026 & - & 0.009 \\
Zinc $(\mathrm{Zn})$ & 0.009 & 0.140 & 0.009 & 0.014 \\
Bromine $(\mathrm{Br})$ & 0.003 & 0.004 & 0.003 & 0.005 \\
Rubidium $(\mathrm{Rb})$ & - & - & - & 0.006 \\
Strontium $(\mathrm{Sr})$ & 0.023 & 0.047 & 0.023 & 0.025 \\
Yttrium $(\mathrm{Y})$ & - & - & - & 0.001 \\
Zirconium $(\mathrm{Zr})$ & 0.004 & 0.007 & - & 0.007 \\
Niobium $(\mathrm{Nb})$ & - & - & 0.002 & - \\
Barium $(\mathrm{Ba})$ & - & 0.017 & - & - \\
Lead $(\mathrm{Pb})$ & 0.127 & 0.008 & 0.013 & 0.008 \\
\hline
\end{tabular}

*Values are expressed in \%age 
was calculated to evaluate the ability of plant for accumulating metals from the substrate. Mobility index (MI) was derived at each level as below:

Mobility Index $(\mathrm{MI})=\underline{\text { Concentration of metals in receiving level }}$

Concentration of metal in source level

Mobility index depicts biomobility and transport of heavy metals through plant-parts, and is necessary to understand the transport mechanism of metals and minerals in different plant components (rhizome, stem, leaves) (Kuntal and Reddy, 2014).

\section{RESULTS}

\section{Elemental Analysis}

To check the elemental composition and biomonitoring of heavy metals, Eichhornia crassipes (Mart.) Solms. was selected as an active biomonitor species in studied wetland. Of 17 heavy metals reported in studied macrophyte, 15 were listed in macrophyte, and 11 in sediments. In macrophyte (whole plant), the maximum concentration of $\mathrm{Fe}$ $(1.537 \%)$ was reported, while $Y(0.001 \%)$ was accumulated in least content. In sediment, $\mathrm{Fe}$

Table 2b: Heavy metals composition in Eichhornia crassipes and Sediment

\begin{tabular}{lcc}
\hline Metals & Sediment & Whole Plant \\
\hline $\mathrm{Ti}$ & 0.662 & 0.253 \\
$\mathrm{Cr}$ & 0.058 & 0.011 \\
$\mathrm{Mn}$ & 0.069 & 0.126 \\
$\mathrm{Fe}$ & 4.371 & 1.537 \\
$\mathrm{Ni}$ & 0.018 & 0.004 \\
$\mathrm{Cu}$ & - & 0.0175 \\
$\mathrm{Zn}$ & - & 0.086 \\
$\mathrm{Br}$ & - & 0.0075 \\
$\mathrm{Rb}$ & 0.011 & 0.029 \\
$\mathrm{Sr}$ & 0.026 & 0.0485 \\
$\mathrm{Nb}$ & 0.004 & 0.002 \\
$\mathrm{Y}$ & - & 0.001 \\
$\mathrm{Zr}$ & 0.032 & 0.009 \\
$\mathrm{Ba}$ & - & 0.0175 \\
$\mathrm{~Pb}$ & - & 0.078 \\
$\mathrm{Sm}$ & 0.039 & - \\
$\mathrm{Ir}$ & 0.013 & - \\
\hline
\end{tabular}

\footnotetext{
* Values are expressed in \%age
}

(4.371\%) showed its maximum concentration, with minimum concentration of $\mathrm{Nb}(0.004 \%)$. Comparing the results obtained from various plantparts of studied species, rhizome was found to accumulate the maximum content of heavy metals (12), followed by tuber and stem (10 each), and the least (8) was noticed in leaves. Of the 12 metals in rhizome, maximum amount of $\mathrm{Fe}(2.627 \%)$ was observed, while $Y(0.001 \%)$ was accumulated in least content. In tuber and stem, highest concentration was noted in case of $\mathrm{Ti}(0.233 \%)$ and Fe $(0.174 \%)$, respectively, whereas the lowermost concentration was observed for $\mathrm{Nb}(0.002 \%)$ and $\mathrm{Br}$ $(0.004 \%)$, respectively. In leaves, Fe $(0.166 \%)$ was accumulated more effectively, with least content of $\mathrm{Ti}(0.051 \%)$. The accumulation trend clearly depicts that $\mathrm{Fe}$ is effectively transported through all the plant systems, and E. crassipes to be the best candidate for remediation of $\mathrm{Fe}$ from the polluted aquatic substrates (Tables 2ab).

\section{Heavy Metals Analyses (Sediment and Plant)}

Of the 17 heavy metals, eight metals were common both in sediment as well studied plant. The content of heavy metals was more $(1.032 \%)$ in rhizosphere than freshwater dominant macrophyte (Eichhornia crassipes) $(0.135 \%)$ in the waters of DSW (Dakor Sacred Wetland), Central Gujarat, India. Overall, eight metals (Ti, Mn, Fe, Zn, Br, Sr, Zr, $\mathrm{Pb}$ ) were common in whole plant as well as sediment. Of which, three metals $(\mathrm{Zn}, \mathrm{Br}, \mathrm{Pb})$ were found to be

Table 3: Difference of heavy metals composition in Eichhornia crassipes and Sediment

\begin{tabular}{lccc}
\hline $\begin{array}{l}\text { Heavy } \\
\text { Metals }\end{array}$ & Sediment & $\begin{array}{c}\text { Whole } \\
\text { Plant }\end{array}$ & Difference \\
\hline $\mathrm{Ti}$ & 0.662 & 0.127 & 0.535 \\
$\mathrm{Mn}$ & 0.069 & 0.016 & 0.053 \\
$\mathrm{Fe}$ & 4.371 & 0.135 & 4.237 \\
$\mathrm{Zn}$ & - & 0.721 & $\mathrm{NA}$ \\
$\mathrm{Br}$ & - & 0.008 & $\mathrm{NA}$ \\
$\mathrm{Sr}$ & 0.026 & 0.020 & 0.007 \\
$\mathrm{Zr}$ & 0.032 & 0.015 & 0.017 \\
$\mathrm{~Pb}$ & - & 0.039 & $\mathrm{NA}$ \\
Mean & 1.032 & 0.135 & 0.062 \\
& & & \\
\hline
\end{tabular}

* Values are expressed in \%age 
exclusive elements in E. crassipes. Of the reported metals, five metals ( $\mathrm{Ti}, \mathrm{Mn}, \mathrm{Fe}, \mathrm{Zr}, \mathrm{Sr}$ ) were found to be common. Among all, the most abundant metal was $\mathrm{Zn}(0.721 \%)$ in macrophyte, with more content of $\mathrm{Fe}(4.371 \%)$ in sediment, while $\mathrm{Br}(0.008 \%)$ was noticed to be minimally concentrated in studied plant, with $\mathrm{Sr}(0.026 \%)$ in sediment. Some metals ( $\mathrm{Ti}, \mathrm{Mn}$, $\mathrm{Zr}, \mathrm{Pb}$ ) exhibited plummeting trend in both substrates (plant and sediment). Of the reported heavy metals, the overall concentration of heavy metals $(0.062 \%)$ was more in sediment compared to the studied plant species (Table 3).

\section{Heavy Metals Analyses (Plant-parts)}

The metal profile in different plant-parts (roots, stems, leaves) of Eichhornia crassipes at DSW was extrapolated. For metal analyses, the studied plant was kept intact (without sorted into plant-parts) as it was in vegetative phase during the post-monsoon period (October, 2014). In total, eight heavy metals ( $\mathrm{Ti}, \mathrm{Cr}$, Mn, $\mathrm{Fe}, \mathrm{Zn}, \mathrm{Br}, \mathrm{Sr}, \mathrm{Zr}, \mathrm{Pb}$ ) were analyzed in plant-parts of studied plant by WD-XRF (Table 4, Figures $3 \mathrm{ab}$ ).

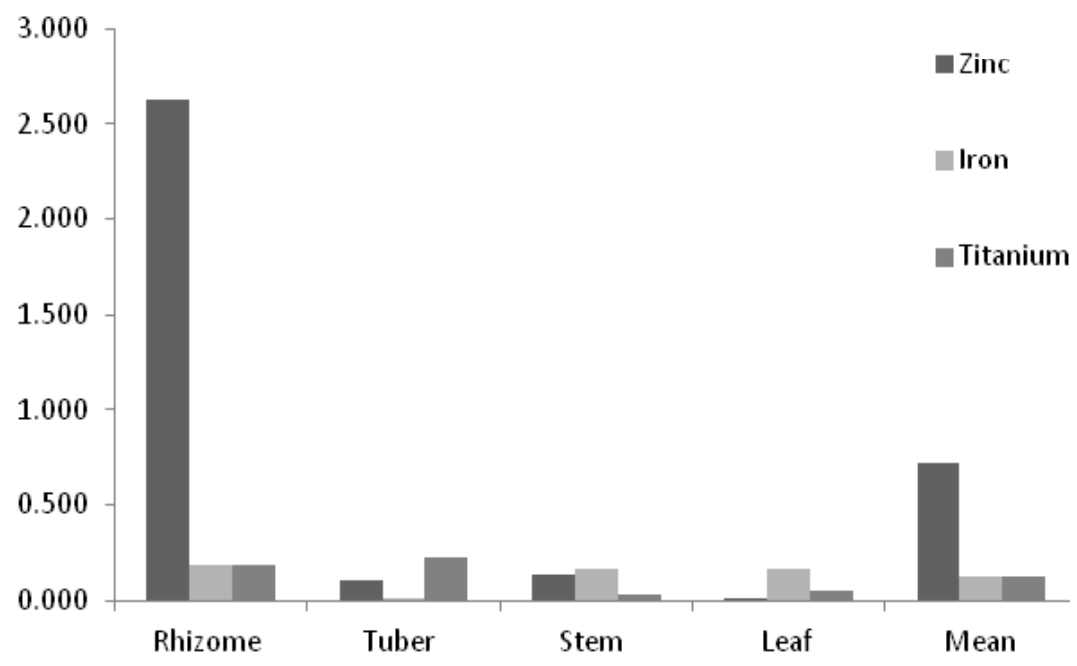

Fig. 3a: Heavy metal concentration in Eichhornia crassipes

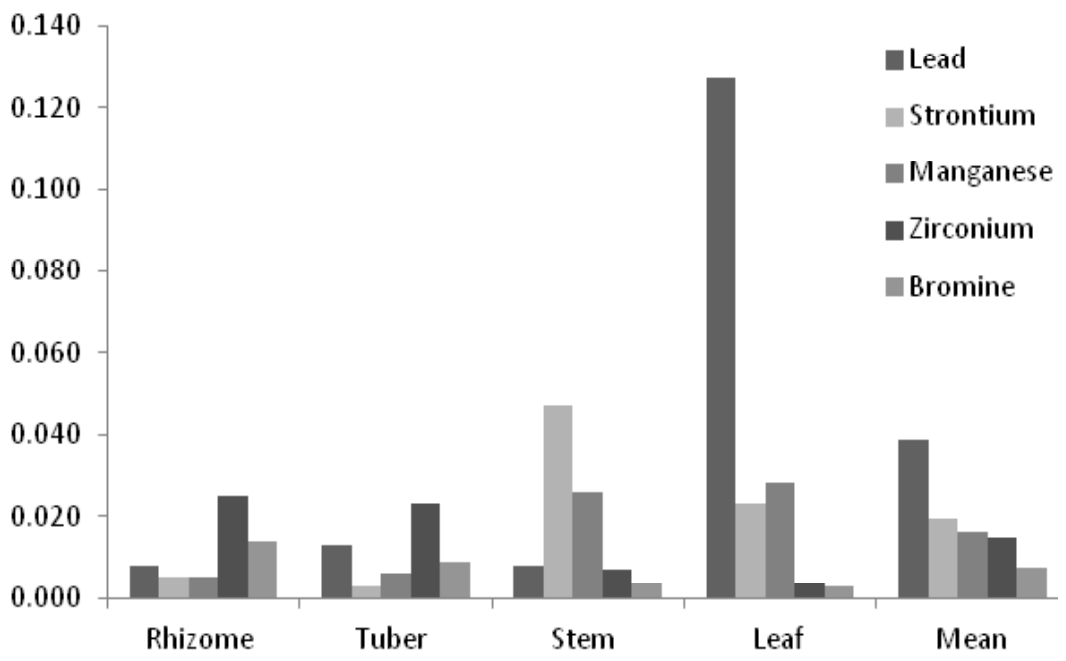

Fig. 3b: Heavy metal concentration in Eichhornia crassipes 


\section{Overall Chain of Transport Mechanism}

Eichhornia crassipes exhibited the maximum positive correlation ( $r=0.431-0.574)$ between stemrhizome (S-R) and stem-leaf (S-L) systems. Metal translocation from rhizome to tuber, and tuber to stem showed moderate positive correlation $(r=$ 0.080-0.339), whereas leaf to tuber (L-T) and leaf to rhizome (L-R) exhibited negative correlation. Thus, the chain of metal transport mechanism in $E$. crassipes is Sediment $>$ Rhizome $>$ Tuber $>$ Stem $>$ Leaf (Table 5).

\section{Translocation of Heavy Metals}

The accumulation of heavy metals in root system of $E$. crassipes was more $(0.383 \%)$ compared to other plant parts. Roots of E. crassipes were exhibiting more cumulative and significant association of $\mathrm{Zn}$ and $\mathrm{Pb}$. Therefore, the studied macrophyte presents an exclusion strategy for these heavy metals. The gradient of Translocation Factor (TF) of heavy metals in experimental macrophyte was receded as: $\mathrm{Zn}>\mathrm{Pb}>\mathrm{Mn}>\mathrm{Sr}>\mathrm{Fe}>\mathrm{Zr}>\mathrm{Ba}$ $>\mathrm{Ti}>\mathrm{Cu}$, indicating contributory role of $E$. crassipes in refining the water quality at source level (Table 6, Figure 4).

$\mathrm{Br}$ and $\mathrm{Ba}$ concentrations showed congruent symmetry in shoots (0.007 and 0.017$)$ and roots (0.007 and 0.018), their Translocation Factor (TF) signifies a transference of metals from underground (root system) to aboveground (shoot system) tissues. $\mathrm{Br}$ and $\mathrm{Ba}$ ions are readily taken up by roots, and translocated into leaves in many plant species (Demirezen and Aksoy, 2004).
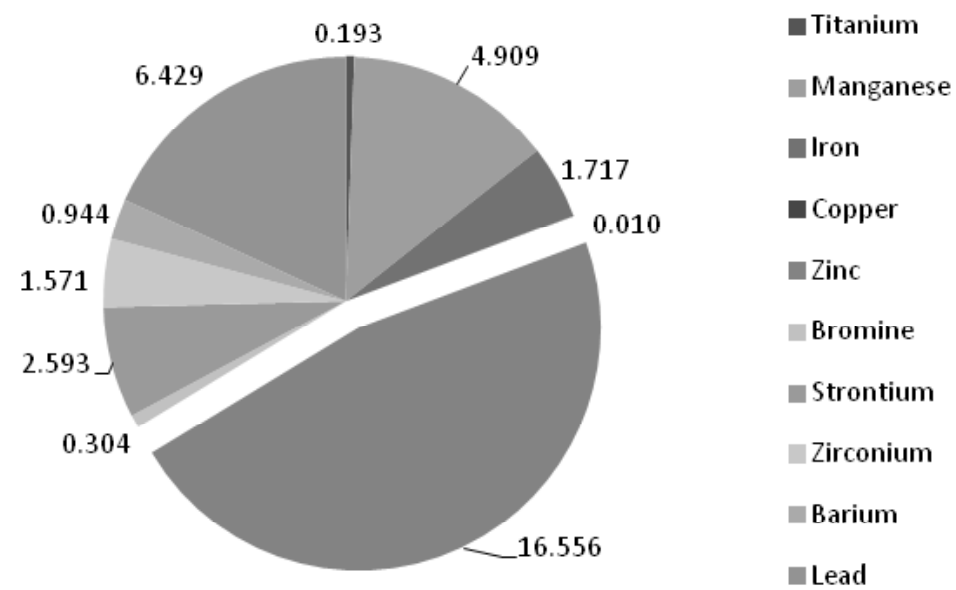

Fig. 4: Translocation factor (TF) in Eichhornia crassipes

Table 4: Descriptive statistics of heavy metal concentration in Eichhornia crassipes (Part-wise)

\begin{tabular}{lllllllll}
\hline \multicolumn{2}{c}{ Metals Leaf } & Stem & Tuber & Rhizome & Mean & Median & S.D. Skewness \\
\hline $\mathrm{Ti}$ & 0.050 & 0.032 & 0.233 & 0.192 & 0.234 & 0.192 & 0.255 & 1.613 \\
$\mathrm{Mn}$ & 0.028 & 0.026 & 0.006 & 0.005 & 0.027 & 0.026 & 0.026 & 1.332 \\
$\mathrm{Fe}$ & 0.166 & 0.174 & 0.012 & 0.186 & 0.982 & 0.174 & 1.896 & 2.228 \\
$\mathrm{Zn}$ & 0.009 & 0.140 & 0.108 & 2.627 & 0.721 & 0.124 & 1.272 & 1.988 \\
$\mathrm{Br}$ & 0.003 & 0.004 & 0.009 & 0.014 & 0.008 & 0.007 & 0.005 & 0.738 \\
$\mathrm{Sr}$ & 0.023 & 0.047 & 0.003 & 0.005 & 0.021 & 0.023 & 0.018 & 0.619 \\
$\mathrm{Zr}$ & 0.004 & 0.007 & 0.023 & 0.025 & 0.018 & 0.023 & 0.012 & -0.285 \\
$\mathrm{~Pb}$ & 0.127 & 0.008 & 0.013 & 0.008 & 0.039 & 0.011 & 0.059 & 1.990 \\
\hline
\end{tabular}

\footnotetext{
*Values are expressed in \%age.
} 


\section{Bioaccumulation factor (BAF)}

Bioaccumulation factor (BAF) [Metal level in underground tissues / Metal level in Near Root Sediment (NRS)] was pooled to assess the capability of $E$. crassipes for uptake of heavy metals from the surrounding sediment source. BAF of heavy metals in experimental plant showed receding trend as: $\mathrm{Mn}$ $>\mathrm{Rb}>\mathrm{Sr}>\mathrm{Ti}>\mathrm{Fe}>\mathrm{Nb}>\mathrm{Zr}>\mathrm{Cr}$. This reflects the tendency of $E$. crassipes to bioconcentrate heavy metals independently and directly from the water.

The value of BAF more than 1 indicates that plants are enriched by particular elements (accumulators), while around 1 indicates a rather indifferent behavior of the plant towards these elements (indicators), and a ratio $<1$ clearly shows

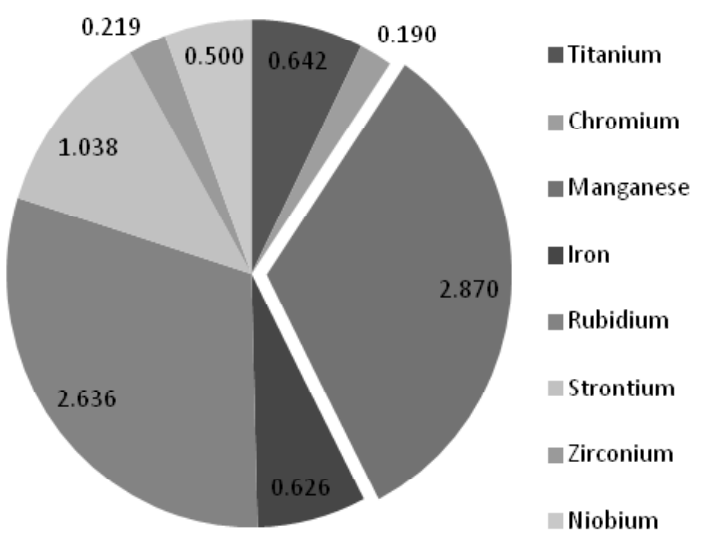

Fig. 5: Bioaccumulation factor (BAF) of Eichhornia crassipes

Table 5: Pearson Correlation Coefficient ( $r$ ) (Part-wise)

\begin{tabular}{lc}
\hline Plant-PartsPair & $\begin{array}{c}\text { Pearson Correlation } \\
\text { Coefficient }(\mathbf{r})\end{array}$ \\
\hline Leaf $\times$ Stem & 0.431 \\
Leaf $\times$ Tuber & -0.121 \\
Leaf $\times$ Rhizome & -0.233 \\
Stem x Tuber & 0.080 \\
Stem x Rhizome & 0.574 \\
Tuber x Rhizome & 0.339 \\
\hline
\end{tabular}

that the plant exclude these elements from uptake (excluders) (Chamberlain, 1983). In studied plant, the value of BAF was observed (>1). Thus, E. crassipes has been found as a better phytoaccumulator species for toxic heavy metals ( $\mathrm{Mn}, \mathrm{Rb}, \mathrm{Sr}$ ). Bioaccumulation factor (BAF) less than 1 was observed in case of $\mathrm{Cr}$, $\mathrm{Zr}, \mathrm{Nb}$, Fe and $\mathrm{Ti}$, indicating a better excluder for the above stated heavy metals (Table 7, Figure 5).

\section{Mobility of Metals}

Mobility index (MI) showed biomobility and translocation of heavy metals at different levels: Level 1 (Sediment-Rhizome), Level 2 (RhizomeTuber), Level 3 (Tuber-Stem) and Level 4 (Stemleaf) in E. crassipes. This becomes essential to apprehend the transport mechanism of heavy metals in macrophyte components of underground and aboveground systems. Present findings revealed that Level 1 (Sediment-Rhizome) was enriched with high mobility rate of $\mathrm{Zr}(0.781 \%)$. In case of Level 2 (Rhizome-Tuber) and Level 4 (Stem-leaf), maximum mobility rate of $\mathrm{Pb}(1.625 \%$ and $15.875 \%$, respectively) was noticed, indicating $\mathrm{Pb}$ to be readily and easily remediated by $E$. crassipes. Sr (15.667) was remediated more after entering Level 3 (TuberStem). Thus, higher mobility gradient of heavy metals among various levels can be expressed as: $\mathrm{Pb}>\mathrm{Sr}$ $>\mathrm{Fe}>\mathrm{Mn}>\mathrm{Ti}>\mathrm{Zr}>\mathrm{Br}>\mathrm{Zn}$. (Table 8, Figure 6).

\section{Causative Factors of Health Hazards}

Five commonly available toxic heavy metals ( $\mathrm{Ti}, \mathrm{Mn}, \mathrm{Fe}, \mathrm{Zr}, \mathrm{Sr}$ ) were detected in both the

Table 6: Translocation factor (TF) of heavy metals in Eichhornia crassipes

\begin{tabular}{lc}
\hline Heavy Metals & Translocation factor(TF) \\
\hline $\mathrm{Ti}$ & 0.193 \\
$\mathrm{Mn}$ & 4.909 \\
$\mathrm{Fe}$ & 1.717 \\
$\mathrm{Cu}$ & 0.010 \\
$\mathrm{Zn}$ & 16.556 \\
$\mathrm{Br}$ & 0.304 \\
$\mathrm{Sr}$ & 2.593 \\
$\mathrm{Zr}$ & 1.571 \\
$\mathrm{Ba}$ & 0.944 \\
$\mathrm{~Pb}$ & 6.429 \\
\hline
\end{tabular}

${ }^{*}$ Values are expressed in \% age 
substrates (plant and sediment), which adversely affect the health of local inhabitants residing nearby localities of DSW due to their erratic and persistent presence in abiotic as well as biotic components of aquatic body. $\mathrm{Zn}$ interferes with the gastro-intestinal, haematological and respiratory tract functioning, Ti deteriorates Respiratory system, Mn affects cardiovascular, hepatic, neurological and respiratory mechanisms, $\mathrm{Pb}$ interferes with body mechanisms; impairs heart, bones, intestines, kidneys, reproductive and nervous systems; obstructs the development of nervous system, and toxic in children, causing learning and behavioral disorders. The minute concentration of Sr adversely affects the musculo-skeletal systems of the human body (ATSDR, 1995; 1996).

Table 7: Bioaccumulation factor (BAF) of Eichhornia crassipes

\begin{tabular}{lc}
\hline $\begin{array}{l}\text { Heavy } \\
\text { Metals }\end{array}$ & $\begin{array}{c}\text { Bioaccumulation } \\
\text { factor (BAF) }\end{array}$ \\
\hline $\mathrm{Ti}$ & 0.642 \\
$\mathrm{Cr}$ & 0.190 \\
$\mathrm{Mn}$ & 2.870 \\
$\mathrm{Fe}$ & 0.626 \\
$\mathrm{Rb}$ & 2.636 \\
$\mathrm{Sr}$ & 1.038 \\
$\mathrm{Zr}$ & 0.219 \\
$\mathrm{Nb}$ & 0.500 \\
\hline
\end{tabular}

\section{DISCUSSION}

In the present work, the studied aquatic macrophyte Eichhornia crassipes (Mart.) Solms. Was found to exhibit heavy metal concentrations in plant-parts (Rhizome, Tuber, Stem, Leaf). Roots of $E$. crassipes absorb heavy metals from the water, and acquire high contents (Baldantoni et al., 2005). The current findings depict the high amount of heavy metals in rhizome of E. crassipes, and the least contents in leaves. Similar results (low metal concentrations in leaf system) were obtained by Nirmal et al. (1989) and Baldantoni et al. (2005). Thus, E. crassipes was found to be the efficient aquatic species for biomonitoring of heavy metals owing to its availability throughout the year at Dakor Sacred Wetland (DSW). The ratio of overall contents of heavy metals was higher in sediments than macrophyte E. crassipes (Ramdan, 2003). Accordingly, the gradient of heavy metals concentration is Sediment $>$ Root system $>$ Stem system $>$ Leaf system. These results reflect that both underground and upper ground systems have natural controlling mechanism for the specific metals absorbed from the proximate environment (Ravera et al., 2003). Negative correlation indicates that retranslocation of metals from shoot to root system in E. crassipes is not feasible, and the metals absorbed are retained in its plant-parts. This also highlights the overall chain of transport mechanism and accumulation of different metals along the abiotic factor (sediment) and the biotic component (plant).

* Values are expressed in \%age

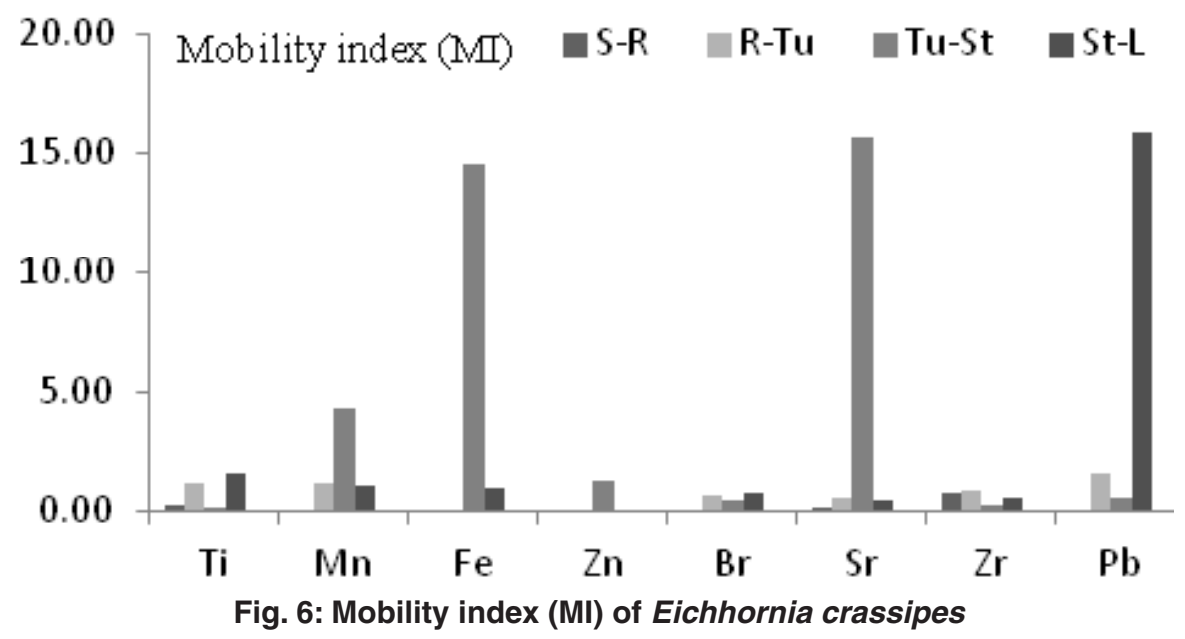


Table 8: Mobility index (MI) of Eichhornia crassipes

\begin{tabular}{ccccc}
\hline $\begin{array}{l}\text { Mobility } \\
\text { index }\end{array}$ & S-R & R-Tu & Tu-St & St-L \\
\hline $\mathrm{Ti}$ & 0.290 & 1.214 & 0.137 & 1.563 \\
$\mathrm{Mn}$ & 0.072 & 1.200 & 4.333 & 1.077 \\
$\mathrm{Fe}$ & 0.043 & 0.065 & 14.500 & 0.954 \\
$\mathrm{Zn}$ & $\mathrm{BDL}$ & 0.041 & 1.296 & 0.064 \\
$\mathrm{Br}$ & $\mathrm{BDL}$ & 0.643 & 0.444 & 0.750 \\
$\mathrm{Sr}$ & 0.192 & 0.600 & 15.667 & 0.489 \\
$\mathrm{Zr}$ & 0.781 & 0.920 & 0.304 & 0.571 \\
$\mathrm{~Pb}$ & $\mathrm{BDL}$ & 1.625 & 0.615 & 15.875 \\
\hline
\end{tabular}

* S: Sediment; R: Rhizome; Tu: Tuber, St: Stem; L: Leaf

Translocation of heavy metals in different plant-parts clearly indicated that root system of $E$. crassipes accumulates more metals than the aboveground tissues (Dunbabin and Bowmer, 1992; Deng et al., 2004), which could be a metal tolerant capacity of the plant (Deng et al., 2004), and plants with such capacity are designated as non-accumulator species. Although $\mathrm{Br}$ and $\mathrm{Ba}$ are not essential for plant (Demirezen and Aksoy, 2004), the present findings depict the translocation and mobility of these metals too effectively by E. crassipes. Translocation mechanism of $\mathrm{Br}$ and $\mathrm{Ba}$ has not been elucidated yet, but its uptake by roots is occurred (probably) via a transport system, perhaps with another essential divalent micronutrient (possibly $\mathrm{Zn}$ ). Bromine (Br) and Barium ( $\mathrm{Ba}$ ) is a chemical analogue of $\mathrm{Zn}$; perhaps the plant could not distinguish between these two ions (Kirkham, 2006). Although E. crassipes is a perennial, floating hydrophyte, exhibiting dry phenophase during winter-summer period, it experiences deciduous phenomenon especially in case of shoots. Ba accumulated in the shoot tissues is incorporated to sediments, which could be a detoxification mechanism of plant $E$. crassipes. Thus indicates its more tendency to accumulate the affinity metals ( $\mathrm{Mn}, \mathrm{Rb}, \mathrm{Sr})$, which may be due to high physiological requirement of $\mathrm{Mn}$ by the studied plant (Mergler et al., 1994; Boucher and Watzin, 1999; Doyle et al., 2003). Present research work indicates that E. crassipes (Mart.) Solms. could be a better remediator species for uptake of $\mathrm{Pb}, \mathrm{Zr}$ and Sr. It reveals that sometimes roots act as hurdle to transfer the toxic metals through soil-plant system
(Jones and Clement, 1972). Jarvis and Robson (1982) observed the accentuated amount of $\mathrm{Zr}$ in root system. Low metal concentration was detected in roots due to high mobility of heavy metals from soil to roots. This indicates the propensity of roots to retain rich amount of metals from soil, and very little is transferred to the above ground system. The results exhibited the conformity with Jarvis et al. (1976) and Leita et al. (1991). The indigenous species may become lenient to such heavy metals for their metabolize and secretion (Abdel Moati, 1985). The concentrations of heavy metals were much lower in plant tissues of the native aquatic species than sediments. Thus, it is recommended that pollution at Dakor Sacred Wetland (DSW) can be abated effortlessly by preventing the excessive anthropogenic loads through point and non-point sources, and the implementation of sophisticated water purification treatments on the drainage points. On-ground wetland management action plans (WPAPs) should be executed by involving local inhabitants, and with managerial assistance from government and non-government nodal agencies within intensive rehabilitation programs for an effective and effectual management of DSW at regional grass-roots level (Payne, 1991). Owing to the sacred significance contriving with human pressures, rare and threatened biotic components should immediately be saved for preservation of its sanctity. Moreover, the DSW should be declared as a Sanctum sanctorum to revive and rejuvenate its prevailing biodiversity not to be deteriorated by momentous anthropogenic interventions. 


\section{CONCLUSION}

Present study clearly illustrates that Eichhornia crassipes (Mart.) Solms. can be signified as the key species (phytoaccumulator and bioaccumulator) for an effective remediation of toxic elements into aquatic environment. Thus, the studied aquatic macrophyte could be used as an active biomonitor plant species to cleanse the contaminated wetlands as it can significantly accumulate, translocate and remediate the perilous heavy metals like $\mathrm{Zn}, \mathrm{Pb}, \mathrm{Mn}, \mathrm{Rb}, \mathrm{Sr}$, Fe, $\mathrm{Nb}, \mathrm{Zr}$, Ba, $\mathrm{Ti}, \mathrm{Cu}$ and $\mathrm{Cr}$, thereby aiding in absolute abatement of toxic and obnoxious elemental contamination of aquatic ecosystem.

\section{ACKNOWLEDGEMENT}

The authors are thankful to Dr. C.L. Patel, Chairman, Charutar Vidya Mandal (CVM) and Dr. V.S. Patel, Director, Sophisticated Instrumentation Centre for Applied Research and Technology (SICART) Gujarat, India, for providing necessary infrastructure, and logistic facilities throughout the tenure of the research work. The second author is grateful to University Grants Commission (UGC), New Delhi, India, for providing financial support under the Maulana Azad National Fellowship (MANF) Scheme.

\section{REFERENCES}

1. Abdel, M.A.R. Studies on the chemistry of lake Manzala waters, Egypt. Unpublished Ph.D. Thesis, Faculty of Science. Alexandria University (1985).

2. Ahluwalia, S.S., Goyal, D. Microbial and plant derived biomass for removal of heavy metals from wastewater. Bioresource Technology. 98(12): 2243-2257 (2007).

3. Allen, S.E. Chemical Analysis of Ecological Materials. $2^{\text {nd }}$ Ed., Blackwell Scientific Publications, Oxford (1989).

4. APHA (American Public Health Association). Standard Methods for the Examination of Water and Wastewater. 22 ${ }^{\text {nd }}$ Ed., American Water Works Association, Water Environment Federation, Washington D.C., U.S.A (2012).

5. ASTER (Assessment Tools for the Evaluation of Risk). ASTER Ecotoxicity Profile. Duluth, MN: Environmental Research Laboratory, U.S. Environmental Protection Agency (1995).

6. ASTER (Assessment Tools for the Evaluation of Risk). Ecotoxicity Profile. Duluth, MN: Environmental Research Laboratory, U.S. Environmental Protection Agency (1996).

7. Baldantoni, D.G., Maisto, G., Bartoli Alfani, A. Analyses of three native aquatic plant species to asses spatial gradients of lake trace element contamination. Aquatic Botany. 83: 48-60 (2005).

8. Biswas, K., Calder, C.C. Handbook of Common
Water and Marsh Plants of India and Burma. xvi + 216, Bishen Singh Mahendra Pal Singh (Dehra Dun) (1994).

9. Boucher, A.M., Watzin, M.C. Toxicity identification evaluation of metal-contaminated sediments using an artificial pore-water containing dissolved organic carbons. Environmental Toxicology and Chemistry. 18: 509-518 (1999).

10. Chamberlain, A.J. Fallout of lead and uptake by crops. Atmospheric Environment. 17: 693706 (1983).

11. Demirezen, D., Aksoy, A. Accumulation of heavy metals in Typha angustifolia (L) and Potamogeton pectinatus (L) living in Sultan Marsh (Kayseri, Turkey). Chemosphere. 56: 685-696 (2004).

12. Deng, H., Ye, Z.H., Wong, M.H. Accumulation of lead, zinc, copper and cadmium by 12 wetland plant species thriving in metalcontaminated sites in China. Environmental Pollution. 132: 29-40 (2004).

13. Doyle, C.J. Pablo, F., Lim, R.P., Hyne, R.V. Assessment of metal toxicity in sediment pore water from lake Macquarie, Australia. Archives of Environmental Conservation and Toxicology. 44: 343-350 (2003).

14. Dunbabin, J.S., Bowmer, K.H. Potential use of constructed wetlands for treatment of industrial wastewaters containing metals. Science and Total Environment. 111: 151-168 
(1992).

15. Jackson, L.J. Paradigms of metal accumulation in rooted aquatic vascular plants. Science and Total Environment. 219: 223-231 (1998).

16. Jarvis, S.C., Jones, L.H.P., Hooper, M.J. Cadmium uptake from solution by plants and its transport from roots to shoot. Plant and Soil. 44: 179-191 (1976).

17. Jarvis, S.C., Robson, A.D. Absorption and distribution of copper in plants with sufficient or deficient supplies. Annals of Botany. 50: 151-160 (1982).

18. Jones, L.H.P., Clement, C.R. Lead uptake by plants and its significance for animals. p. 2933. In: P. Hepple, Ed. Lead in the Environment. Applied Science Publishers, Barking (1972).

19. Kirkham, M.B. Cadmium in plants on polluted soils: Effects of soils factors, hyperaccumulation, and amendments. Geoderma. 137: 19-32 (2006).

20. Kuntal, S., Reddy, M.N. Accumulation of heavy metals by some aquatic macrophytes in estuarine zone of River Tapi, Surat, Gujarat, India. International Journal of Innovative Research in Science, Engineering and Technology. 3(4): 11125-11134 (2014).

21. Leita, L., Enne, G., De, N.M., Baldini, M., Sequi, P. Heavy metal bioaccumulation in lamb and sheep bred in smelting and mining areas of S.W. Sardinia (Italy). Bulletin of Environmental Contamination and Toxicology. 46: 887-893 (1991).

22. Maiti, S.K. Handbook of Methods in Environmental Studies. Vol. I. Water and Wastewater Analysis. ABD Publications, Jaipur (India). 307 p (2003).

23. Mergler, D., Huel, G., Bowler, R., Iregren, A., Belanger, S., Baldwin, M., Tardif, R., Smargiassi, A., Martin, L. Nervous system dysfunction among workers with long-term exposure to manganese. Environmental Research. 64: 151-180 (1994).

24. Nirmal, K.J.I., Soni, H., Kumar, R.N. Evaluation of biomonitoring approach to study lake contamination by accumulation of trace elements in selected aquatic macrophytes: A case study of Kanewal Community Reserve. Applied Ecology and Environmental Research. 6 (1): 65-76 (2007).

25. Nirmal, K.J.I., Soni, H., Kumar, R.N. Bhatt,
I. Macrophytes in phytoremediation of heavy metal contaminated water and sediments in Pariyej Community Reserve, Gujarat, India. Turkish Journal of Fisheries and Aquatic Sciences. 8(2): 193-200 (2008).

26. Nirmal, K.J.I., Das, M., Mukherji, R., Kumar, R.N. Trace metal contents in water, sediment and hydrophytes at a freshwater wetland in Central Gujarat, India. Bulletin of Environmental Science and Research. 1(1): 16-24 (2012).

27. Nirmal, K.J.I., Soni, H., Kumar, R.N. Biomonitoring of selected freshwater macrophytes to assess lake trace element contamination: A case study of Nal Sarovar Bird Sanctuary, Gujarat, India. Journal of Limnology. 65(1): 9-16 (2006).

28. Nirmal, K.J.I., Sreenivas, S., Rana, B.C. EDAX analysis of mud of four ponds from Central Gujarat. Indian Botanical Contractor. 6: 5-7 (1989).

29. Payne, N.F. Techniques for Wildlife Habitat Management of Wetlands (Biological Resource Management). McGraw-Hill Inc., USA. ISBN (978-0070489554). 549 p (1991).

30. Pip, E., Stepaniuk, J. Cadmium, copper and lead in sediments and aquatic macrophytes in the Lower Nelson River System., Manitoba, Canada. I. Interspecific differences and macrophyte - sediment relations. Archives of Hydrobiology. 124: 337-355 (1992).

31. Ramdan, A.A. Heavy metal pollution and biomonitoring plants in Lake Manzala, Egypt. Pakistan Journal of Biosciences. 6(13): 11081117 (2003).

32. Ravera, O., Cenci, R.G.M., Beon, M., Dantas Lodigiani, P. Trace element concentrations in freshwater mussels and macrophytes as related to those in their environment. Journal of Limnology. 62(1): 61-70 (2003).

33. Rodgers, W.A., Panwar, H.S. Planning $A$ Wildlife Protected Area Network in India. 2 Vols. Project FO: IND/82/003. FAO, Dehra Dun. 339 p (1988).

34. Shah, G.L. Flora of Gujarat State. Vols. I \& II. University Press, S.P. University, Vallabh Vidyanagar, Gujarat, India (1978).

35. Singh, Y.D., Joshua, J., Sunderraj, S.F.W., Oswin, S.D., Joshi, P.N., Joshi, N.M., Soni, 
$\mathrm{H}$. Conservation of Rare and Endangered Biodiversity of Gujarat (CREB). Final Technical Report submitted to Gujarat Ecology Commission (GEC), Gujarat. $343 p$ (2002).

36. Soni, H.B., Thomas, S. Preliminary observations on phytoplankton at sacred palustrine habitat, Central Gujarat, India. International Journal of Environment. 2(1): 115-126 (2013a).

37. Soni, H.B., Thomas, S. Preliminary assessment of surface water quality of tropical pilgrimage wetland of Central Gujarat, India. International Journal of Environment. 2(1): 202-223 (2013b).

38. Soni, H.B., Thomas, S. Preliminary data on occurrence of zooplanktons of freshwater lentic ecosystem - A case study of Dakor Sacred Wetland, Central Gujarat, India. International Journal of Environment. 1(1): 46-55 (2013c).

39. Soni, H.B., Thomas, S. Historical perspectives and future perceptions of sacred pilgrimage spot of Central Gujarat, India - A case study of Gomti Water Tank. Present Environment and Sustainable Development. 7(2): 47-57 (2013d).
40. Soni, H.B., Thomas, S. Associative dependence among plankton and macrophytes as pollution markers at tropical lentic environ, Gujarat, India. International Journal of Environment. 3(2): 175-191 (2014).

41. Stolz, M., Greger, M. Accumulation properties of $\mathrm{As}, \mathrm{Cd}, \mathrm{Cu}, \mathrm{Pb}$ and $\mathrm{Zn}$ by four wetland plant species growing on submerged mine tailings. Environment and Experimental Botany. 47: 271-280 (2002).

42. Szymanowska, A., Samecka, C.A., Kempers, A.J. Heavy metals in three lakes in West Poland. Ecotoxicology and Environmental Safety. 43: 21-29 (1999).

43. Tsekova, K., Todorova, D., Dencheva, V., Ganeva, S. Biosorption of copper (II) and cadmium (II) from aqueous solutions by free and immobilized biomass of Aspergillus niger. Bioresource Technology. 101: 1727-1731 (2010).

44. Vardanyan, I.G., Ingole, B.S. Studies on heavy metal accumulation in aquatic macrophytes from Sevan (Armenia) and Carambolin (India) lake systems. Environment International. 32: 208-218 (2006). 